DOI: https://dx.doi.org/10.4314/sinet.v44i1.4

\title{
Some physiochemical properties of termite mound soil and its effect on yield and yield components of maize (Zea mays L.) Under Greenhouse condition at Nekemte, western Ethiopia
}

\author{
Temesgen Beyene* and Emana Getu
}

Addis Ababa University, College of Natural and Computational Sciences Addis Ababa, Ethiopia. E-mail: temesgenbeyene2012@gmail.com

\begin{abstract}
Termite mound soil amends soil fertility and utilized as an alternative to NPK fertilizers by smallholder farmers in Africa. Experiment was conducted in western Ethiopia to compare selected physical and chemical properties of mound soil (ms), Adjacent soil (AS) and non-mound soil (NMS) and the effect of these soils on maize plant growth and yield in the Greenhouse. In Limu district, Fitbako kebele, cultivated land was purposively selected for sampling. In the cultivated land, a plot of $100 \mathrm{~m}$ $\mathrm{x} 100 \mathrm{~m}$ was delineated and three mounds within the plot were also purposively selected to collect composite soil sample for soil analysis and Greenhouse pot experiment. From each mound, 10kg soil each from bottom, middle and top (total $=30 \mathrm{~kg}$ ) were collected and mixed to obtain working sample of $10 \mathrm{~kg}$. About $30 \mathrm{~kg}$ of adjacent soil $5 \mathrm{~m}$ away from mound soils and Non-mound soil at the distance of 20 $\mathrm{m}$ away from mound soil at the depth of $0-30 \mathrm{~cm}$ were collected and thoroughly mixed to make working sample of $10 \mathrm{~kg}$ from each soil type. Three kilograms of mound soil, adjacent soil and non-mound soil each was put in separate plastic bucket for greenhouse pot experiment. About 100 gm of each soil type was used for selected physical and chemical properties analyses. The result obtained demonstrated that termite mound soil was significantly $(\mathrm{P}<0.05)$ high in bulk density $(\mathrm{BD})$, moisture contents $(\mathrm{MC})$, porosity $(\mathrm{P})$, Soil $\mathrm{pH}$, percent organic carbon (\% OC) and percent organic matter (\% OM). Total Nitrogen (TN), average (av.) P, av. K, Exch. Ca and Exch. Mg were also significantly $(\mathrm{P}<0.05)$ higher in mound soil in comparison with adjacent soil and non-mound soil. Maize plant growth traits and yield were significantly $(\mathrm{P}<0.05)$ high in mound soil. From the current study, it can be concluded that the use of NPK fertilizer on plots having termite mound is not recommended. However, further research is needed on how to use mound soil on large plot of land.
\end{abstract}

\section{Key words/Phrases: Adjacent soil, Chemical property of soil, Non-mound soil, Soil texture, Termite mound soil}

\section{INTRODUCTION}

Termites are considered to be one of the most destructive pests in the world, but termite mound soil amends soil fertility and utilized as an alternative to NPK fertilizers by cash constrained smallholder farmers in some parts of Africa (Abdeta Jembere et al., 2017). However, there is little knowledge on mound soil texture, nutritional composition and the impact it has on plant growth and yield in western Ethiopia particularly Nekemte areas where high maize production, high termite mound distribution and termite infestations exists. Termites mostly feed on dead plant matter like woodchip, decayed wood $(\operatorname{logs})$, leaf litter and soil. They are considered as major pests of cereals such as maize, sorghum and teff among others (Daniel Getahun and Emana Getu, 2014). Termites are also important component of agro-ecosystems as their mounds amend nutrient depleted soils. Termites are large and diverse group of soil fauna consisting over 3000 species in 280 genera and seven families in the world (Daniel Getahun and Emana Getu, 2014). In Africa, there are about 1000 termite species (Abdurahman Abdulahi, 1990). Termite prevalence survey conducted in western, southern, and eastern parts of Ethiopia provided basic information on termite fauna of Ethiopia (Daniel Getahun and Emana Getu, 2014). In Ethiopia, there are 61 species of termites belonging to 25 genera and four families (Abdeta Jembere et al., 2017). Termites live in their own mound. The density of termite in a mound depends on the size of the mound. Subterranean termites mound harbor 3,000-200,000 individual termites. Termite mound is constructed from a mixture of soil, termite saliva and dung/plant materials. The top of the mound consists of a central chimney surrounded by an intricate

${ }^{*}$ Author to whom correspondence should be addressed. 
network of tunnels and passages (Daniel Getahun and Emana Getu, 2014). The genus Macrotermes builds large mounds that have a characteristic feature of many grasslands and savanna woodlands in Africa. Termite genera that build mound include Macrotermes, Cubitermes, Amitermes, Odontotermes, Procubitermes and Trinervitermes (Abdurahman Abdulahi, 1990). Mound building termites are abundant in degraded low soil fertility and high soil acidity areas particularly in areas that were converted to pasture (Rückamp, 2012). Termites feed on a whole range of living and dead plant materials and decompose it to concentrate nutrients in the mound. It is with the aid of soil dwelling free living $\mathrm{N}_{2}$ fixing bacteria, Azotobacter and Bacillus that termites digest the foraged materials and decompose it to organic matter (Sathiya et al., 2018).These admixtures in one hand alter the natural texture of soil and on the other hand accumulate more soil organic carbon (OC), organic matter (OM), $\mathrm{pH}, \mathrm{Ca}, \mathrm{K}, \mathrm{N}$ and $\mathrm{Mg}$ in mound soil (Jouquet et al., 2011). Such kind of termite's mound debris/organic matter and nutrients content amends soil fertility for the better functioning of the ecosystem (Bonachela et al., 2015). Termites act of bioturbation changed soil texture and make it more porous (Jouquet et al., 2015). Dhembare et al. (2015 reported mound making termites such as Macrotermes and Odontotermes significantly influence soil properties and amend soil fertility. Nigerian savanna region farmers and others including the highlanders of resource poor farmers of southwest Ethiopia use termite mound soil as fertilizer (Abdeta Jembere et al., 2017). Small holder famers use termite mound soil as a fertilizer mainly due to inflated cost of commercial fertilizer. Fageria and Baliga (2005) after testing it on improved maize variety recommended the use of mound soil in combination with NPK fertilizer as it has improved plant growth that led to high yield. Therefore, the objective of the current study was to analyze some physiochemical properties of mound soil and its effect on yield and yield components of maize in western Ethiopia under greenhouse pot experiment condition.

\section{MATERIALS AND METHODS}

\section{Description of the study area}

The Greenhouse experiment was conducted at Wollega University (WU) in East Wollega zone,
Western Ethiopia (Figure 1) from October 2018 and June 2019. The study was conducted at $905.887^{\prime} \mathrm{N}$ latitude, 36 $34.647^{\prime} \mathrm{E}$ longitude and at an elevation of 2080 meter above sea level (m.a.s.l.). The maximum and minimum temperatures of the area were $21.66^{\circ} \mathrm{C}$ and $13.62^{\circ} \mathrm{C}$, respectively. The relative humidity was $55.45 \%$ and the average annual rain fall was $1862.33 \mathrm{~mm}$. The study area, Nekemte town was $335 \mathrm{~km}$ away from Addis Ababa to the West.

\section{Termite Sampling and Identification}

Mounds in the cultivated land were dug and opened with hoe. Termite soldier samples which came out of the mound for defense were handcollected with forceps and were preserved in $80 \%$ ethanol following Abdurahaman Abdulahi (1990), and Daniel Getahun and Bekele Jembere (2006) procedures. Collected specimens were taken to Addis Ababa University, Insect Science Laboratory for identification. Morphological identification was done using Keys for the Genera of Ethiopian Termites. Moreover, books/proceedings, pictures and reference collections were used for the identification (Emana Getu et al., 2008). The shape and the size of the mandible were the major features considered for the identification.

\section{Experimental materials}

Samples of termite mound soil, adjacent soil and non-mound soil were collected from cultivated land of Limu district, Fitbako kebele in Eastern Wollega zone. Widely grown maize variety, BH-661 and NPK fertilizer were obtained from Zone Office of Ministry of Agriculture based at Nekemte town.

\section{Pot preparation and filling of soil in the pot}

Plastic buckets having 50 litters capacity were purchased from local market. The buckets were perforated at the distance of $5 \mathrm{~cm}$ from the bottom with nail to prevent inundation. From the stock of Mound soil (MS), Adjacent soil (AS) and Nonmound soil (NMS) three kilogram each were weighed and added to each bucket following Ezekiel et al. (2018) procedures. After filling the pots with appropriate soil sample based on the treatment, all buckets were kept at one-meter distance and watered two days before planting. All buckets were watered twice per day throughout the experimental period. Fertilizer was applied at 
the rate of $150 \mathrm{~kg} /$ ha following Ezekiel et al. (2018) procedure. Two maize seeds were planted in circular hole having $15 \mathrm{~cm}$ depth and $30 \mathrm{~cm}$ diameter made with finger in each bucket. Two weeks after planting when the seedlings attained two leaves stage, one seedling was removed to minimize competition. Weeding was done by hand and deposited in their respective buckets.

\section{Experimental design and Treatments}

The experiment was laid out in a completely randomized design (CRD) with three replications. The treatments were Mound soil (MS), Adjacent soil (AS), Non-mound soil, NPK (15: 15: 15), MS+AS, MS+NPK, MS+NMS, AS+NPK, AS+NMS, NMS+NPK, MS+AS+NPK AND MS+AS+NPK+NMS.

\section{Data collection}

Termite genera composition, termite mound soil, adjacent soil and non-mound soil selected physical and chemical properties, plant growth traits at 2, 4 and 8 weeks after planting and yield (g or $\mathrm{kg}$ ) were some of the data that were collected.
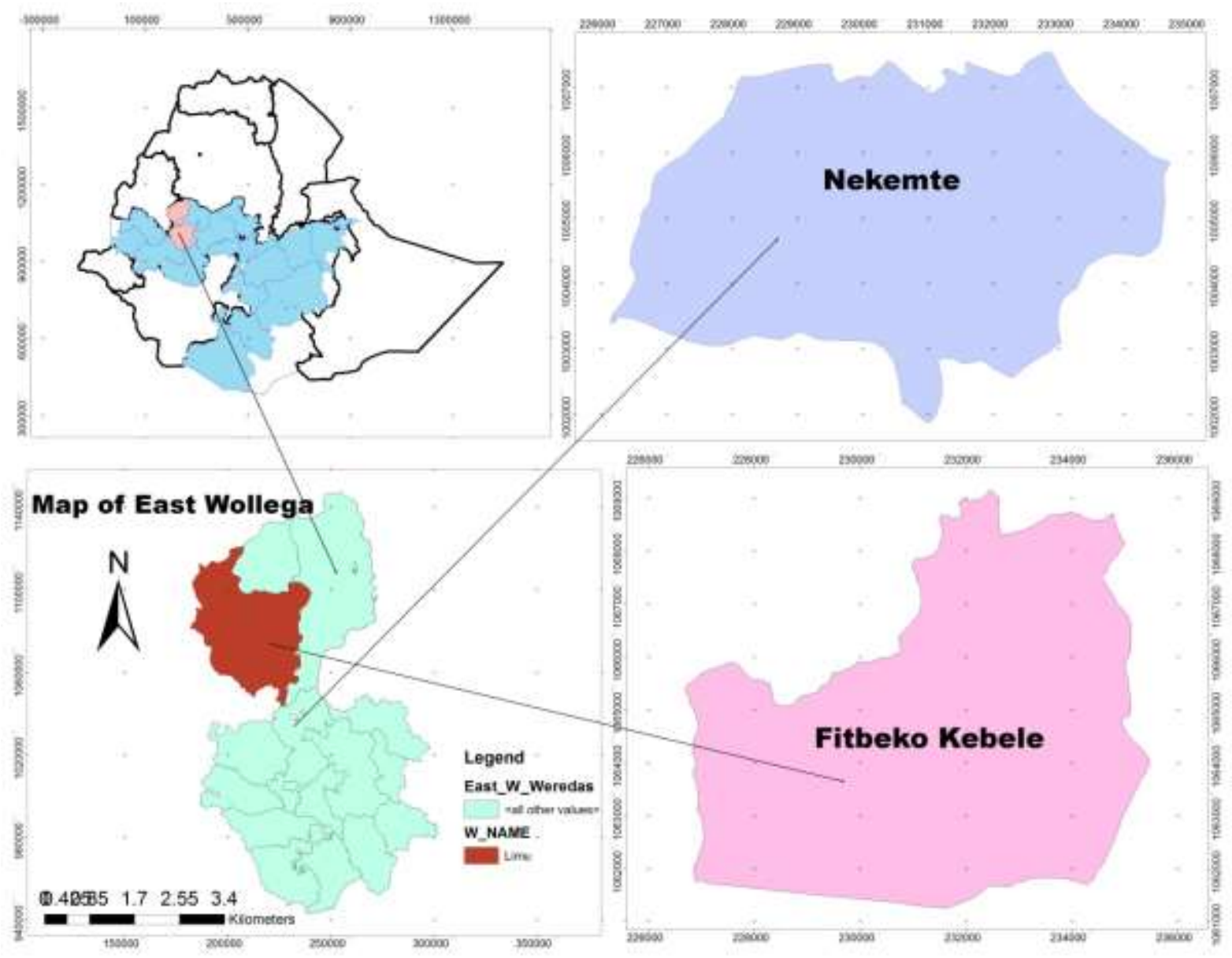

Figure 1. Map of the study area.

\section{Soil Sampling and analysis}

A plot of $100 \mathrm{~m} \times 100 \mathrm{~m}$ was delineated from cultivated land for sampling. Three mounds within the plot were marked with permanent marker randomly. Soil samples were taken from bottom, middle and top of the termite mounds and mixed up thoroughly to get composite sample of $10 \mathrm{~kg}$ from the three mounds. Composite soil sample collection of $10 \mathrm{~kg}$ was done at the depth of 0-30 $\mathrm{cm}$ using auger for adjacent soil $5 \mathrm{~m}$ away from the mounds. Composite non-mound soil of $10 \mathrm{~kg}$ at similar depth with that of adjacent were collected 
$20 \mathrm{~m}$ away from the mounds following Daniel Getahun and Emana Getu (2014) procedures. From each soil types, $3 \mathrm{~kg}$ were drawn and used for physiochemical analyses based on National Soil Research Centre of Ethiopia (2000) established procedure. Then some selected physical and chemical properties were analyzed. Soil particle size distribution was determined using hydrometer method. Available potassium (Av. K) was analyzed by extracting with Morgan's solution and measuring by flame photometer. Total nitrogen (TN) was determined by the Kjeldahl procedure (Gupta, 2000). Organic Carbon (OC) content was determined after wet oxidation by the dichromate method. Soil organic matter contains $58 \% \mathrm{C}$. Conversion of \% C to \% OM was done with the empirical factor of 1.724, which was obtained by dividing 100 by 58. Available phosphorus (Av. P) was determined by spectrophotometer following Olsen "method using glass electrode (Olsen, 1954). The pH of the soil was measured potention metrically on direct reading $\mathrm{pH}$ meter in water suspension with soil to water ratio of 1:2.5. Exchangeable basic cations $(\mathrm{Ca}, \mathrm{Mg}, \mathrm{K}$ and $\mathrm{Na}$ ) were extracted with $1 \mathrm{M}$ ammonium acetate at $\mathrm{pH}$ 7. Exchangeable $\mathrm{Ca}$ and $\mathrm{Mg}$ were determined from this extract with atomic absorption spectrophotometer, while exchangeable $\mathrm{K}$ and $\mathrm{Na}$ were determined from the same extract with flame photometry (Abera Donis and Kefyalew Assefa, 2017). The soils were analyzed at Bako Agricultural Research Centre soil laboratory.

\section{Statistical analysis}

Analysis for the effect of Mound soil, NPK, Adjacent soil and Non-mound soil on growth trait and maize yield component were done using ANOVA using SAS software version 9.1. Significant means were separated using Tukey's Studentized Range Test (HSD) at 5\% significance level (SAS, 1999).

\section{RESULTS AND DISCUSSION}

\section{Termite diversity}

Termite genera collected from Fitbako kebele mounds were shown in Table 1. Macrotermes and Odontotermes were the termite genera recorded. About $75 \%$ of the termites were from the Genus Macrotermes. Macrotermes subhyalinus (Rambur) species were collected from mound1 and mound 2, while Macrotermes herus (Sjoestedt) were collected from mound 3.

Table 1. Termites' Genera composition of Fitbako kebele.

\begin{tabular}{lll}
\hline Termite mounds & Termites genera \\
\cline { 2 - 3 } & Macrotermes & Odontotermes \\
\hline Mound 1 & 25 & 0 \\
Mound 2 & 20 & 0 \\
Mound 3 & 0 & 15 \\
Composition (\%) & 75 & 25 \\
\hline
\end{tabular}

Selected physical properties of mound soil, adjacent soil and non-mound soil

Selected physical property of mound soil, adjacent soil and non-mound soil were analyzed from composite soil were shown in Table 2. The bulk density of mound soil was higher than adjacent soil and non mound soil. However, bulk densities of termite mound, adjacent soil and nonmound soils were at the normal value range of $1.02-1.35 \mathrm{~g} / \mathrm{cm}^{3}$ as compared to agricultural soils.

The moisture content of mound soil was higher than adjacent soil and non mound soil. This indicates the availability of sufficient water in mound soil which can be used for normal plant growth. The porosity of mound soil was higher than the adjacent soil and non-mound soil. However, the porosity values of termite mound soil, adjacent soil and non-mound soil are more than the normal soil porosity value of $50 \%$ which suffices for crop production.

Table 2. Laboratory analyses of Bulk density, moisture content and porosity of mound, adjacent soil and non-mound soil of Fitbako kebele.

\begin{tabular}{llll}
\hline Soil type & $\begin{array}{l}\text { Bulk density } \\
\left(\mathrm{g} / \mathrm{cm}^{3}\right)\end{array}$ & $\begin{array}{l}\text { Moisture } \\
\text { content }(\%)\end{array}$ & $\begin{array}{l}\text { Porosity } \\
(\%)\end{array}$ \\
\hline Mound soil & 1.04 & 13.20 & 60.16 \\
Adjacent soil & 1.24 & 10.1 & 52.35 \\
Non-mound & 1.0 & 8.5 & 52.56 \\
soil & & & \\
\hline
\end{tabular}

Selected chemical properties of mound soil, adjacent soil and non-mound soil

Selected chemical properties of termite mound soil, adjacent soil, and non-mound analyzed from composite soil samples are shown in Table 3. Non-mound soil had the lowest $\mathrm{pH}$, while that of mound soil was the highest. Organic carbon (OC) in mound soil was the highest. 
However, the mound, adjacent and non-mound values are less than the standard range value of OC $(>3 \%)$ for agricultural soil. The mound soil had higher organic matter (OM) with the value of $4.88 \%$ than the adjacent soil $(1.30 \%)$ and non-mound soil $(1.21 \%)$ present medium range of OM (3-5\%) compared to crop land soil. The highest total nitrogen $(\mathrm{TN})(0.14 \%)$ was observed in mound soil and the lowest TN $(0.04 \%)$ was recorded on Nonmound soil. All the TN values recorded were lower than the range value of $(\mathrm{TN})(0.25 \%)$. The highest concentration of $9.00 \mathrm{ppm}$ was recorded from mound soil, while the lowest $7.23 \mathrm{ppm}$ of $\mathrm{P}$ was recorded from non-mound soil. The highest exchangeable $\mathrm{Ca}$ and $\mathrm{Mg}$ values were
$7.70 \mathrm{meq} / 100 \mathrm{~g}$ and $1.90 \mathrm{meq} / 100 \mathrm{~g}$ in mound soil. Mound soil had more $(\mathrm{k})(1.97 \mathrm{cmol} / \mathrm{kg}$ soil than adjacent soil $(0.96 \mathrm{cmol} / \mathrm{kg}$ soil $)$ and non-mound soil $(0.56 \mathrm{cmol} / \mathrm{kg}$ soil). However, the value of $\mathrm{K}$ in mound soil, adjacent soil and non-mound soil were greater than the critical level of $\mathrm{K} 0.38$ $\mathrm{cmol} / \mathrm{kg}$ soil for crop production. Slightly higher $\mathrm{Mg}$ (1.90meq/100g soil) content was found in mound soil than adjacent soil $\mathrm{Mg}=1.87 \mathrm{meq} / 100 \mathrm{~g}$ soil) and non- mound soil $(\mathrm{Mg}=1.86 \mathrm{meq} / 100 \mathrm{~g}$ soil). However, the value of $\mathrm{Mg}$ in mound soil, adjacent soil and non-mound soil were greater than the critical level of $\mathrm{Mg}(0.50 \mathrm{meq} / 100 \mathrm{~g}$ soil $)$ for the soil used for crop production.

Table 3. Selected chemical properties of Mound soil adjacent soil and Non-mound soil Fitbako kebele.

\begin{tabular}{lllllllll}
\hline Categories & $\begin{array}{l}\mathrm{PH} \\
(1: 1.25)\end{array}$ & $\begin{array}{l}\% \\
\mathrm{OC}\end{array}$ & \%OM & $\% \mathrm{TN}$ & $\begin{array}{l}\text { Ava. } \\
\mathrm{P}(\mathrm{ppm})\end{array}$ & $\begin{array}{l}\text { Ex. } \\
\mathrm{K}(\mathrm{cmol} / \mathrm{kg} \\
\text { soil) }\end{array}$ & $\begin{array}{l}\text { Ex.Ca } \\
(\mathrm{meq} / 100 \mathrm{gs} \\
\text { oil) }\end{array}$ & $\begin{array}{l}\text { Ex.Mg } \\
(\mathrm{Meq} / 100 \mathrm{~g} \\
\text { soil) }\end{array}$ \\
\hline Mound soil & 5.44 & 2.83 & 4.88 & 0.14 & 9.00 & 1.97 & 7.70 & 1.90 \\
& & & & & & & & \\
Adjacent & 5.10 & 0.76 & 1.30 & 0.06 & 7.30 & 0.96 & 7.33 & 1.87 \\
Non-mound soil & 4.5 & 0.35 & 1.21 & 0.04 & 7.23 & 0.56 & 7.21 & 1.86 \\
\hline
\end{tabular}

Effect of termite mound soil, adjacent soil and non-mound soil on maize plant growth traits two weeks after planting

Effects of termite mound soil, adjacent soil and non-mound soil on maize growth traits two weeks' after planting were shown in Table 4 . Treatments' effects were significantly different $(\mathrm{p}<0.05)$ two weeks after planting. The highest plant height $(32 \mathrm{~cm})$ was recorded from the four treatments' combination i.e. MS+AS+NPK+NMS, while the lowest plant height $(16.04 \mathrm{~cm})$ was recorded from plants grown on non-mound soil.

As shown in Table 4, termite mound soil alone and termite soil combined with other treatments significantly $(\mathrm{P}<0.05)$ affected plant growth. The highest stem width was observed in four combined treatments (MS+AS+NPK+NMS), while the lowest plant's stem width was recorded from non-mound soil. Plants grown with NPK and treatments' combination (MS+ AS+NPK+NMS) significantly $(\mathrm{P}<0.05)$ higher in number of leaves and leaf width than adjacent and non-mound soil
Table 4. Effect of termite mound soil, adjacent soil and Non-mound soil on means ( \pm se) of maize growth traits two weeks after planting

\begin{tabular}{|c|c|c|c|c|}
\hline *Treatments & $\begin{array}{l}\text { Plant } \\
\text { height } \\
(\mathrm{cm})\end{array}$ & $\begin{array}{l}\text { Stem } \\
\text { width } \\
(\mathrm{cm})\end{array}$ & $\begin{array}{l}\text { No. of } \\
\text { leaf }\end{array}$ & $\begin{array}{l}\text { Leaf } \\
\text { width } \\
(\mathrm{cm})\end{array}$ \\
\hline MS & $24.1 \pm 2.7 \mathrm{c}$ & $2.80 \pm 0.26^{\mathrm{ab}}$ & $8 \pm 1.8^{\mathrm{cd}}$ & $2.8 \pm 0.27 \mathrm{bc}$ \\
\hline AS & $18.0 \pm 1.8^{\mathrm{e}}$ & $2.30 \pm 0.24^{\mathrm{de}}$ & $7 \pm 1.8^{\text {de }}$ & $2.5 \pm 0.25^{\mathrm{cd}}$ \\
\hline NPK & $23.6 \pm 2.7 \mathrm{~cd}$ & $2.75 \pm 0.24^{b c}$ & $7.2 \pm 1.8^{a}$ & $2.4 \pm 0.25^{\mathrm{ab}}$ \\
\hline NMS & $16.4 \pm 1.7^{f}$ & $2.04 \pm 0.21^{\mathrm{e}}$ & $6.0 \pm 1.8^{e}$ & $2.1 \pm 0.23^{\mathrm{d}}$ \\
\hline $\mathrm{MS}+\mathrm{AS}$ & $25.0 \pm 2.7^{b}$ & $2.60 \pm 0.24^{\mathrm{cd}}$ & $8 \pm 1.8^{\mathrm{cd}}$ & $2.4 \pm 0.25^{\mathrm{cd}}$ \\
\hline $\mathrm{MS}+\mathrm{NPK}$ & $30.0 \pm 2.9 \mathrm{ab}$ & $2.87 \pm 0.26^{b}$ & $9 \pm 1.8^{\mathrm{bc}}$ & $2.7 \pm 0.25^{\mathrm{cd}}$ \\
\hline MS +NMS & $24.0 \pm 2.7 \mathrm{~cd}$ & $2.70 \pm 0.24^{\mathrm{cd}}$ & $8 \pm 1.8^{\mathrm{cd}}$ & $2.6 \pm 0.25^{\mathrm{cd}}$ \\
\hline AS+NPK & $20 . .0 \pm 1.8^{\mathrm{d}}$ & $2.50 \pm 0.24^{\mathrm{d}}$ & $7 \pm 1.8^{\text {de }}$ & $2.5 \pm 0.25^{\mathrm{cd}}$ \\
\hline AS+NMS & $18.0 \pm 1.8^{e}$ & $2.30 \pm 0.24^{\mathrm{de}}$ & $7 \pm 1.8^{\mathrm{de}}$ & $2.5 \pm 0.25^{\mathrm{cd}}$ \\
\hline NMS+NPK & $17.4 \pm 1.7$ ef & $2.04 \pm 0.21^{\mathrm{e}}$ & $6.0 \pm 1.8^{\mathrm{e}}$ & $2.1 \pm 0.23^{\mathrm{d}}$ \\
\hline $\mathrm{MS}+\mathrm{AS}+\mathrm{NMS}$ & $24.1 \pm 2.7^{c}$ & $2.80 \pm 0.26^{\mathrm{ab}}$ & $8 \pm 1.8^{\mathrm{cd}}$ & $2.8 \pm 0.27 \mathrm{bc}$ \\
\hline $\begin{array}{l}\mathrm{MS}+\mathrm{AS}+ \\
+\mathrm{NPK}+\mathrm{NMS}\end{array}$ & $32.0 \pm 2.9^{a}$ & $3.16 \pm 0.24^{\mathrm{a}}$ & $10 \pm 1.8^{\mathrm{a}}$ & $3.5 \pm 0.29 \mathrm{a}$ \\
\hline
\end{tabular}

*MS= mound soil, AS=adjacent soil, NPK: N= Nitrogen, $P=$ Phosphorus and $\mathrm{K}=$ Potassium, NMS = Non-mound soil.

Means followed by the same letter (s) within a column are not significantly different from each other at 5\% level, Tukey's Studentized Range Test (HSD). 
Effect of termite Mound soil, NPK, Adjacent soil, Non-mound soil on maize plant growth traits four weeks after planting

Maize plant growth traits were significantly $(\mathrm{P}<0.05)$ high on plants grown on treatments combination except number of leaves which were not statistically different $(\mathrm{P}>0.05)$ in all treatments four weeks after planting (Table 5). Maize plant growth traits were significantly $(\mathrm{P}<0.05)$ low in non-mound soil.

Table 5. The effect of termite Mound soil, NPK, Adjacent, and Non- mound soil on mean ( \pm se) maize growth trait four weeks after planting.

\begin{tabular}{lllll}
\hline $\begin{array}{l}\text { *Treatmen } \\
\text { ts }\end{array}$ & $\begin{array}{l}\text { Plant } \\
\text { height }(\mathrm{m})\end{array}$ & $\begin{array}{l}\text { Stem } \\
\text { width }(\mathrm{cm})\end{array}$ & No. of leaf & $\begin{array}{l}\text { Leaf width } \\
(\mathrm{cm})\end{array}$ \\
\hline MS & $67.10 \pm 9.35^{\mathrm{c}}$ & $7.12 \pm 1.36^{\mathrm{ab}}$ & $10.0 \pm 2.2^{\mathrm{a}}$ & $7.5 \pm 2.19^{\mathrm{b}}$ \\
AS & $53.20 \pm 7.32^{\mathrm{f}}$ & $5.67 \pm 0.98^{\mathrm{d}}$ & $9.6 \pm 2.2^{\mathrm{a}}$ & $5.6 \pm 2.19^{\mathrm{d}}$ \\
NPK & $66.89 \pm 9.35^{\mathrm{d}}$ & $7.02 \pm 1.36^{\mathrm{b}}$ & $10.0 \pm 2.2^{\mathrm{a}}$ & $6.98 \pm 2.19^{\mathrm{c}}$ \\
NMS & $50.2 \pm 7.29 \mathrm{~g}$ & $4.30 \pm 0.80 \mathrm{e}^{\mathrm{e}}$ & $9.3 \pm 2.2^{\mathrm{a}}$ & $4.9 \pm 2.19^{\mathrm{e}}$ \\
MS+AS & $64.30 \pm 9.35^{\mathrm{e}}$ & $6.13 \pm 1.21^{\mathrm{bc}}$ & $9.0 \pm 2.2^{\mathrm{a}}$ & $7.0 \pm 2.19^{\mathrm{bc}}$ \\
MS+NPK & $76.30 \pm 10.7$ & $7.25 \pm 1.36^{\mathrm{ab}}$ & $10.0 \pm 2.2^{\mathrm{a}}$ & $8 \pm 2.19 \mathrm{ab}$ \\
& $2^{\mathrm{b}}$ & & & \\
MS+NMS & $67.10 \pm 9.35^{\mathrm{c}}$ & $7.12 \pm 1.36^{\mathrm{ab}}$ & $10.0 \pm 2.2^{\mathrm{a}}$ & $7.5 \pm 2.19^{\mathrm{b}}$ \\
AS+NPK & $66.34 \pm 9.35^{\mathrm{d}}$ & $6.27 \pm 1.21^{\mathrm{bd}}$ & $9.9 \pm 2.2^{\mathrm{a}}$ & $6.9 \pm 2.19^{\mathrm{bc}}$ \\
AS+NMS & $56.2 \pm 7.29 \mathrm{~g}$ & $4.35 \pm 0.80 \mathrm{e}^{\mathrm{e}}$ & $9.3 \pm 2.2^{\mathrm{a}}$ & $4.9 \pm 2.19^{\mathrm{e}}$ \\
NMS+NP & $53.20 \pm 7.32^{\mathrm{f}}$ & $5.67 \pm 0.98^{\mathrm{d}}$ & $9.6 \pm 2.2^{\mathrm{a}}$ & $5.6 \pm 2.19^{\mathrm{d}}$ \\
K & & & & \\
MS+AS+N & $77.30 \pm 10.7$ & $7.25 \pm 1.36^{\mathrm{ab}}$ & $10.0 \pm 2.2^{\mathrm{a}}$ & $8 \pm 2.19 \mathrm{ab}$ \\
PK & $2^{\mathrm{b}}$ & & & \\
MS+AS+N & $80 \pm 11.41^{\mathrm{a}}$ & $7.30 \pm 1.36^{\mathrm{a}}$ & $10.4 \pm 2.2^{\mathrm{a}}$ & $10 \pm 2.19^{\mathrm{a}}$ \\
Pk+NMS & & & & \\
\hline
\end{tabular}

${ }^{*} M S=$ mound soil, AS=adjacent soil, NPK: $N=$ Nitrogen, $P=$ Phosphorus and $\mathrm{K}=$ Potassium, NMS = Non-mound soil .

Means followed by the same letter (s) within a column are not significantly different from each other at 5\% level, Tukey's Studentized Range test (HSD).

Effect of termite mound soil, adjacent soil and non-mound soil on maize plant growth traits eight weeks after planting

Plant height $(\mathrm{cm})$, stem width $(\mathrm{cm})$, No. of leaf and leaf width $(\mathrm{cm})$ eight weeks after planting showed significant $(\mathrm{p}<0.05)$ variations among the treatments except for the plant height (Table 6). The highest stem width $(9.2 \mathrm{~cm})$ and the highest leaf width $(9.4 \mathrm{~cm})$ were recorded from four combined treatments, respectively and the lowest stem width $(5.13 \mathrm{~cm})$ and the leaf width $(5.7 \mathrm{~cm})$ were recorded from NMS, respectively
Table 6. The effect of termite Mound soil, Adjacent soil, NPK and Non-mound soil on mean ( \pm se) maize growth trait eight weeks after planting.

\begin{tabular}{lllll}
\hline *Treatments & $\begin{array}{l}\text { Plant } \\
\text { height } \\
(\mathrm{cm})\end{array}$ & $\begin{array}{l}\text { Stem } \\
\text { width(c } \\
\mathrm{m})\end{array}$ & $\begin{array}{l}\text { No } \\
\text { leaf }\end{array}$ & $\begin{array}{l}\text { of } \\
\text { Leaf } \\
\text { Width } \\
(\mathrm{cm})\end{array}$ \\
\hline MS & $1.32 \pm 0.1$ & $8.5 \pm 1.18$ & $11.0 \pm 0.86$ & $7.6 \pm 1.0$ \\
& $7^{\mathrm{a}}$ & $\mathrm{bc}$ & $\mathrm{ab}$ & $6^{\mathrm{bc}}$ \\
As & $1.44 \pm 0.1$ & $5.13 \pm 1.1$ & $11.01 \pm 0.8$ & $6.5 \pm \mathrm{d} 1.0$ \\
& $7^{\mathrm{a}}$ & $8^{\mathrm{d}}$ & $6^{\mathrm{ab}}$ & 6 \\
NPK & $1.3 \pm 0.17$ & $7.53 \pm 1.1$ & $11.8 \pm 0.86$ & $6.7 \pm 1.0$ \\
& $\mathrm{a}$ & $8^{\mathrm{d}}$ & $\mathrm{ab}$ & $6^{\mathrm{cd}}$ \\
NMS & $1.3 \pm 0.17$ & $5.03 \pm 1.1$ & $11.2 \pm 0.86$ & $5.7 \pm 1.0$ \\
& $\mathrm{a}$ & $8^{\mathrm{f}}$ & $\mathrm{ab}$ & $6^{\mathrm{e}}$ \\
MS+AS & $1.32 \pm 0.1$ & $6.5 \pm 1.18^{\mathrm{e}}$ & $10.9 \pm 0.86$ & $7.0 \pm 1.0$ \\
& $7^{\mathrm{a}}$ & & $\mathrm{ab}$ & $6^{\mathrm{c}}$ \\
MS+NPK & $1.5 \pm 0.17$ & $8.9 \pm 1.18$ & $11.2 \pm 0.86$ & $7.7 \pm 1.0$ \\
& $\mathrm{a}$ & $\mathrm{b}$ & $\mathrm{ab}$ & $6^{\mathrm{b}}$ \\
MS+NMS & $1.41 \pm 0.1$ & $9.2 \pm 1.18^{\mathrm{a}}$ & $12.3 \pm 0.86$ & $9.4 \pm 1.0$ \\
& $7^{\mathrm{a}}$ & & $\mathrm{ab}$ & $6^{\mathrm{a}}$ \\
AS+NPK & $1.32 \pm 0.1$ & $7.5 \pm 1.18$ & $10.8 \pm 0.86$ & $7.1 \pm 1.0$ \\
& $7^{\mathrm{a}}$ & $\mathrm{de}$ & $\mathrm{ab}$ & $6^{\mathrm{c}}$ \\
AS+NMS & $1.4 \pm 0.17$ & $8.9 \pm 1.18$ & $11.2 \pm 0.86$ & $7.7 \pm 1.0$ \\
& $\mathrm{a}$ & $\mathrm{b}$ & $\mathrm{ab}$ & $6^{\mathrm{b}}$ \\
NMS+NPK & $1.5 \pm 0.17$ & $5.03 \pm 1.1$ & $11.2 \pm 0.86$ & $5.7 \pm 1.0$ \\
& $\mathrm{a}$ & $8^{\mathrm{f}}$ & $\mathrm{ab}$ & $6^{\mathrm{e}}$ \\
MS+AS+NPK & $1.51 \pm 0.1$ & $9.2 \pm 1.18^{\mathrm{a}}$ & $12.3 \pm 0.86$ & $9.4 \pm 1.0$ \\
& $7 \mathrm{a}$ & & $\mathrm{ab}$ & $6^{\mathrm{a}}$ \\
MS+AS+NPK+ & $1.61 \pm 0.1$ & $9.2 \pm 1.18^{\mathrm{a}}$ & $12.3 \pm 0.86$ & $9.4 \pm 1.0$ \\
NMS & $7^{\mathrm{a}}$ & & $\mathrm{ab}$ & $6^{\mathrm{a}}$ \\
\hline
\end{tabular}

${ }^{*} M S=$ mound soil, AS=adjacent soil, NPK: $N=$ Nitrogen, $P=$ Phosphorus and K= Potassium, NMS = Non-mound soil.

Means followed by the same letter within a column are not significantly different from each other at 5\% level, Tukey's Studentized Range test (HSD).

Effect of termite mound Soil, adjacent and nonmound soil on yield components at harvest.

The effect of termite mound soil, adjacent soil and non-mound soil on mean number of maize yield components at harvest was shown in Table 7.There was no significant difference $(p>0.05)$ between the plant height. However, other maize plant growth performance and yield were significantly affected $(\mathrm{p}<0.05)$ by application of treatments. In cob, there was significant difference among the applied treatments. However, all the recorded treatments are all most revealed similar mean number of cobs. ANOVA of grain yield per pot shows significantly difference $(\mathrm{P}<0.05)$ among the treatments (Table 7). As revealed in the result, the highest grain yield per pot was recorded from combined MS+AS+PK+NMS treatments and the lowest grain yield were recorded from non-mound soil. 
Termites are considered to be one of the most destructive pests in the world. But, termite mound soil amends soil fertility and utilized as an alternative to NPK fertilizers by cash constrained smallholder farmers in some parts of Africa. However, there is little knowledge on mound mineral nutritional value and the impact they have on plant growth and yield in western Ethiopia particularly Nekemte areas where high maize production, high termite mound distribution and termite infestations is there. As illustrated in the result, statistically significant difference $(\mathrm{P}<0.05)$ was observed in yield per pot form all treatments at harvest (Table7). The highest yields were recorded from four MS+AS+NPK+NMS combined treatments and the lowest yield per pot was observed from non-mound soil. Significant yield production was also observed in MS and further more yield was recorded from four mixed treatment MS+NPK+AS+NMS than Non -mound soil (Table 7).

Table 7. Effect of termite Mound soil, NPK, Adjacent and Non-mound soil on mean ( \pm se) of maize yield components.

\begin{tabular}{llll}
\hline *Treatments & $\begin{array}{l}\text { Plant } \\
\text { height } \\
(\mathrm{m})\end{array}$ & $\begin{array}{l}\text { No of } \\
\text { cobs per } \\
\text { plant }\end{array}$ & $\begin{array}{l}\text { Yield per } \\
\text { plant }(\mathrm{gm})\end{array}$ \\
\hline MS & $3.53 \pm 0.01^{\mathrm{a}}$ & $2.7 \pm 0.46^{\mathrm{ab}}$ & $1.59 \pm 0.19^{\mathrm{b}}$ \\
As & $3.57 \pm 0.01^{\mathrm{a}}$ & $2.2 \pm 0.46^{\mathrm{c}}$ & $1.5 \pm 0.19^{\mathrm{bc}}$ \\
NPK & $3.52 \pm 0.01^{\mathrm{a}}$ & $2.5 \pm 0.46^{\mathrm{b}}$ & $1.4 \pm 0.19 \mathrm{c}$ \\
NMS & $3.52 \pm 0.01^{\mathrm{a}}$ & $2 \pm 0.46^{\mathrm{d}}$ & $1 \pm 0.19 \mathrm{~d}$ \\
MS+AS & $3.55 \pm 0.01^{\mathrm{a}}$ & $2.3 \pm 0.46^{\mathrm{bc}}$ & $1.3 \pm 0.19 \mathrm{~cd}$ \\
MS+NPK & $3.54 \pm 0.01^{\mathrm{a}}$ & $2.3 \pm 0.46^{\mathrm{bc}}$ & $1.6 \pm 0.19 \mathrm{ab}$ \\
MS+NMS & $3.53 \pm 0.01^{\mathrm{a}}$ & $2.7 \pm 0.46^{\mathrm{ab}}$ & $1.59 \pm 0.19 \mathrm{~b}$ \\
AS+NPK & $3.53 \pm 0.01^{\mathrm{a}}$ & $2.3 \pm 0.46^{\mathrm{bc}}$ & $1.3 \pm 0.19 \mathrm{~cd}$ \\
AS+NMS & $3.53 \pm 0.01^{\mathrm{a}}$ & $2.3 \pm 0.46^{\mathrm{bc}}$ & $1.3 \pm 0.19^{\mathrm{cd}}$ \\
NMS+NPK & $3.53 \pm 0.01^{\mathrm{a}}$ & $2.3 \pm 0.46^{\mathrm{bc}}$ & $1.3 \pm 0.19^{\mathrm{cd}}$ \\
MS+AS+NPK & $3.55 \pm 0.01^{\mathrm{a}}$ & $2.3 \pm 0.46^{\mathrm{bc}}$ & $1.3 \pm 0.19^{\mathrm{cd}}$ \\
MS+AS+NPK+NMS & $3.55 \pm 0.01^{\mathrm{a}}$ & $3 \pm 0.46^{\mathrm{a}}$ & $1.93 \pm 0.19^{\mathrm{a}}$ \\
\hline
\end{tabular}

${ }^{*} M S=$ mound soil, AS=adjacent soil, NPK: N= Nitrogen, $P=$ Phosphorus and $K=$ Potassium, NMS = Non-mound soil.

Means followed by the same letter within a column are not significantly different from each other at 5\% level, Tukey's Studentized Range test (HSD).

\section{DISCUSSION}

In the analyzed experimental result, the selected physiochemical properties of mound soil; bulk density, moisture content, porosity and soil; \% OM, $\%$ OC, TN, $\mathrm{P}, \mathrm{pH}, \mathrm{Ex}, \mathrm{Ca}, \mathrm{Mg}$ and $\mathrm{K}$ were found higher and. are effective in crop production than non-mound soil. The current findings were in line with the finding of Alemu Lelago and Tadele Buraka (2019) that reported termite induce the change in physical and chemical properties of mound soil better than non-mound soil, These physicochemical variation in termite soil was attributed by foraging termites Macrotermes collected from majority of labeled mounds than Odontotermes. In accordance to this, Sutuma Edossa Wako (2015), demonstrate that each mound consisted of dissimilar colonies of termites. The result of bulk density recoded in the current study, showed higher in mound soil than non-mound soil. In accepting this, Arshad et al. (2010) stated that, the termite mounds had higher bulk density than the surrounding soil reveal termites repack soils with their saliva to form hard protective layers against open air and temperature fluctuation in the mounds. In current study moisture content of mound soil was greater than the non-mound soil. This is accepted by Kaschuk et al. (2006) who reported that, termite increase soil depth and regulate water flow into the soil for efficient use of water by crops. In selected analyzed soil chemical properties soil; \% OM, \% OC, $\mathrm{TN}, \mathrm{P}, \mathrm{pH}, \mathrm{Ex}, \mathrm{Ca}, \mathrm{Mg}$ and $\mathrm{K}$ showed higher in mound soil than non-mound soil. In agreement with this, Alemu Lelago and Tadele Buraka (2019), stated, chemicals recorded in termite mound soil were found higher than those in non-mound soil, In supporting this, Daniel Getahun Debelo and Emana Getu Degaga, (2014) reported that exch. cations $(\mathrm{Ca}, \mathrm{Mg}, \mathrm{Na}$ and $\mathrm{K})$, were significantly higher in termite mounds than in non-mound soil and higher values of organic matter $\% \mathrm{OM}$ and slightly acidic $\mathrm{pH}$, were also recorded in mound soil than in anon-mound soil, this result was accepted by Jouqu et al. (2014) who stated that the mound soil organic matter is increased significantly due to the high amount of mound soil organic matter return from organic debris or plant living tissue foraged and degraded during mound construction. In contrast to this, Susumu et al. (2011) reported that cations had contributed more alkaline to the mound soil and make it (slightly to moderately alkaline) values than non-mound soils. Daniel Getahun and Emana Getu (2014) in supporting, stated there is a small increase in $\mathrm{pH}$ of Macrotermitinae when compared with the subsoil from which the mounds are constructed but there is little difference with the topsoil 
Plant growth trait; Plant height, stem and leaf width and leaves number of maize growth were significantly higher from mound soil and more growth was attained from (MS+AS+NPK+ NMS) than non-mound soil. Subsequently this growth induce cob to retain more yield per plant. In accepting this, Daniel Getahun and Emana Getu (2014) states maize grown on mound perimeter produces larger cobs and this led to subsequent increase in yield than the one grown far from mound. Because in mound soil there were significantly higher values of \% TN, ex. Ca, \% OM, average $\mathrm{K}$ and available $\mathrm{P}$. In accepting this, Sileshi Gudeta et al. (2009), reported, significantly higher plant biomass and grass growth around termitaries compared with the ones grown far away from mounds. As revealed from the result, plant grown in nonmound soil appear yellowish and poor stand stem, while, deep green in mound soil and deeper and well performed stem in MS+AS+NPK+NMS. This is in accordance with Daniel Getahun Debelo and Emana Getu Degaga (2014) who reported that, crops grown on soils in mound perimeter were dark green while the ones grown on non-mound soil were yellowish in color. In accepting this, Rajagopal (2015) also states plants from treated plots were tall and dark green with large-sized stems and ears, whereas the plants from the untreated plots were relatively weak and lanky(tall and thin),Mixture MS+AS+NPK+NMS application were found to be highly effective on maize growth performance and resulted in better yield production than from non- mound soil, in agreement with this Ezekiel et.al (2018) and Olowoboko et al. (2017) reported that, the application of inorganic fertilizer NPK to mound soil facilitates growth of the maize crop. Fageria and Baligar (2005) also stated that, number of panicles, shoot in rice and pods in bean dry weights of shoot and grain of upland rice and common bean grown on termite mound soil were significantly increased by the application of NPK treatment.

\section{CONCLUSION AND RECOMMENDATION}

In the current study it was conceived that mound soil exceed in most of the analyzed selected physical soil; Bulk density, Moisture content, Porosity and chemical properties soil; $\mathrm{pH}, \% \mathrm{OM}, \%$ $\mathrm{TN}, \mathrm{Ca}, \mathrm{Mg}$, av. $\mathrm{P}$ and $\mathrm{K}$ than non-mound soil.
Physiochemical backup of mound soil was attributed by termites Macrotermes, and Odontotermes forages. From the current study it can be concluded that mound soil amends soil fertility than non-mound soil and allow effective maize growth performance, better maize growth and subsequent increase in yield/pot was attainedfrom mound soil mixed with As, NPK and NMS. The use of NPK fertilizer on plots having termite mound is not recommended. However, further research is needed on how to use mound soil on large plot of land.

\section{ACKNOWLEDGMENT}

The authors are grateful to the Department of Zoological Sciences of Addis Ababa University for financial support from the student fund and the thematic Research entitled "Niche Shift of Chilopartellus (Swinhoe) in Ethiopia". The support we got from Wollega University is highly invaluable. All friends and colleagues who directly or indirectly contributed to the success of this study are highly acknowledged.

\section{REFERENCES}

1. Abdeta Jembere, Gezahegn Berecha and Alemayehu Regassa (2017). Impacts of termites on selected soil physicochemical characterstics in the highlands of southwest Ethiopia. Archives of Agronomy and Soil Science 63: 1676-684.

2. Abdurahman Abdulahi (1990). Foraging activity and control of termites in Western Ethiopia. Ph.D.Thesis, Imperial College University of London, UK. 275pp.

3. Abera Donis and Kefyalew Assefa (2017). Characterization of Physicochemical Properties of Soils as Influenced by Different Land Uses in Beadle Area in Ilubabor Zone, Southwestern Ethiopia. Journal of Natural Sciences Research 7: 627-636.

4. Alemu Lelago and Tadele Buraka (2019). Determination of physico-chemical properties and agricultural potentials of soils in Tembaro District, KembataTembaro Zone, Southern Ethiopia. Eurasian Journal of Soil Science 8:11830.

5. Arshad, M. (2010). Physical and chemical properties of termite mounds of two species of Macrotermes (is foraging activioptera, Termitidae) and the surrounding soils of the semiarid savanna of Kenya. Journal of soil science 13:120-190.

6. Bonachela, J., Pringle, R., Sheffer, E., Coverdale, T., Guyton, T., Caylor, K., Levin, S. (2015). Termite 
mounds can increase the robustness of dry land ecosystems to climatic change. Science 3: 651655.

7. Daniel Getahun and Emana Getu (2014). Studies on Ecology of mound-building termites in the Central rift valley of Ethiopia International Journal of Agricultural Sciences 4: 326-333.

8. Emana Getu, Abrham Tadesse, Mulugeta Negeri, Tadele Tefera, Hadush Tsaheye and Asmare Dejene (2008). Review of Entomological Research on Maize, Sorghum and Millet. Abraham Tadesse (ed.) Proceedings of the 14th Annual Conference of the Plant Protection Society of Ethiopia (PPSE), 19-22 December 2006, Addis Ababa, Ethiopia. PP 167-244.

9. Ezekiel, P. (2018).Effect of Termite Mound on Growth of Maize in the Humid Forest of Southern Nigeria. Journal of Agriculture and Veterinary Science 11: 22-24.

10. Fageria, N. and Baliga, V. (2005). 'Properties of Termite Mound Soils and Responses of Rice and Bean to Nitrogen, Phosphorus, and Potassium Fertilization on such Soil', Communications in Soil Science and Plant Analysis 35: 15-16.

10. Gupta, P. (2000). Soil, Plant, Water and Fertilizer Analyses. Agrobis India. 438pp.

11. Dhembare A. (2015). Physico-chemical properties of termite mound soil. Archives of Applied Science Research 5:123-126.

12. Jouquet, P., Traore, S., Choosai, C., Hartmann, C. and. Bignell, D. (2011). Influence of termite on ecosystem functioning: ecosystem services provided by termites. European Journal of Soil Biology 47: 215-222.

13. Jouquet, P., Blanchard E, Capowiez Y. (2014). Utilization of earthworms and termites for the restoration of ecosystem functioning. Applied Soil Ecology 73: 34-40.

14. Jouquet P., Guileful N, Chintakunta S, Mendez M, Subramanian S, Shanbhag R. (2015) The influence termites on soil sheeting properties varies depending on the materials on which they feed. European Journal Soil Biology 69:74-89.

15. Kaschuk G, Julio C., Jaime A., Deise C., João F. (2006). Termite Activity in Relation to Natural Grassland Soil Attributes. Science Agriculture 63: 583-588.

16. Meyer, V., Braack, L, Biggs H., Ebersohn, C. (1999). Distribution and density of termite mounds in the northern Kruger National Park, with specific reference to those constructed by Macrotermes Holmgren (Isoptera: Termitidae). African Entomology 7: 123-130.

17. National Soil Research Center (2000). Procedures for soil and plant analysis. Technical paper No.74. Ethiopian Agricultural Research Organization. Addis Ababa, Ethiopia. 110 pp.

18. Olowoboko,T., Onasanya1, O., Salami and Azeez, J. (2017). Growth and Uptake in Maize as Influenced by NPK Fertilizer in Green House Experiment. International Journal of Plant $\mathcal{E}$ Soil Science 17: 1-10.

19. Olsen, S., Cole, C., Watanabe, F. and Dean, L. (1954). Estimation of available phosphorus in soils by extraction with sodium carbonate. USDA circular 939: 1-19.

2o. Pearce, M. (1997). Termites: Biology and Pest Management. CAB International, New York. 172 pp.

21. Rajagopal, P. (2015). Effect of termite mound soil on plant growth Tropical Pest Management http:/ / www.tandfonline.com

22. Rückamp., D, Martius, C, Bornemann, L, Kurzatkowski, D., Naval, L, Amelung W. (2012). Soil genesis and heterogeneity of phosphorus forms and carbon below mounds inhabited by primary and secondary termites. Geoderma 170: 239-50.

23. SAS (1999). The Statistical Analysis System, Statistical Methods. SAS Institute Inc, Cary, NC.

24. Sathiya, P., Bama, C and David Ravindran, A. (2018). Influence of Combined Termite Mound Materials and Inorganic Fertilizers on Growth Parameters of Maize under Non-Sterilized Pot Culture Study Elixir. Appl. Zoology 125: 5230352305.

25. Sileshi Gudeta, Nyeko, P., Sekamate, B., Akinnifesi, F., Ajayi, O. (2009) Integrating ethno-ecological and scientific knowledge of termites for sustainable termite management and human welfare in Africa. Ecology and Society 14: 48-68. [Online] URL: http://www.ecologyandsociety .org/vol14/iss1/art48/.

26. Susumu, S., Yoshinori, W., Taisuke, O., Takashi, K., Toshiyuki, W. (2011). Nutrient Storage in Termite (Macrotermes bellicosus). Mounds and the Implications for Nutrient Dynamics in a Tropical Savanna Ultisol, Japanese. Journal of Soil Science Plant 57: 786-795. 